RISE AND DECLINE OF CIVILIZATIONS:

LESSONS FOR THE JEWISH PEOPLE 


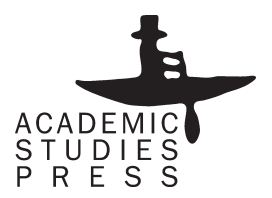




\section{RISE AND DECLINE OF CIVILIZATIONS:}

\section{LESSONS FOR THE JEWISH PEOPLE}

Shalom Salomon Wald

Foreword by Shimon Peres

Boston • Jerusalem • 2014 


\section{IIIPPI $/ /$ \\ www.jppi.org.il}

המכון למדיניות העם היהודי (מיסודה של הסוכנות היהודית לא"י) בע"מ

The Jewish People Policy Institute (Established by the Jewish Agency for Israel) Ltd.

Library of Congress Cataloging-in-Publication Data:

A catalog record for this title is available from the Library of Congress.

Copyright (C) 2014 Academic Studies Press

All rights reserved

ISBN 978-1-61811-276-7 (hardback)

ISBN 978-1-61811-377-1 (paperback)

ISBN 978-1-61811-277-4 (electronic)

Book design by Ivan Grave

Published by Academic Studies Press in 2014

28 Montfern Avenue

Brighton, MA 02135, USA

press@academicstudiespress.com

www.academicstudiespress.com 
To the memory of my mother Regina-Rifka Wald-Lakser who passed away in 1989 after a hard life of flight and survival, and to the memory of my father Nathan Nachman Wald, the brothers and sisters of both my parents, their spouses and children, and all our other close relatives who perished in 1941 and 1942 in the Shoah. 
